\title{
Sağ lobektomiyle sonuçlanan aberran sağ hepatik kanal zedelenmesi
}

\author{
Aberrant right hepatic duct injury resulted in right hepatic lobectomy
}

Muhammet Yener AKPINAR, Serkan TORUN, Erkin ÖZTAŞ, Zeki Mesut Yalın KILIÇ, Bülent ÖDEMIŞ

Türkiye Yüksek Ihtisas Hastanesi Gastroenteroloji Kliniği, Ankara

Sağ aberran hepatik kanal \%4,6-8,4 slklikta izlenilen bir safra yolu varyasyonudur. Aberran hepatik kanal zedelenmesi klinikte farklı şekillerde kendini gösterebilir. Burada, kolesistektomi esnasında oluşan sağ aberran hepatik kanal zedelenmesi sonucu kendini intrahepatik taş oluşması ve kolanjit atakları ile gösteren bir kadın olgu sunduk. Bu olgunun tedavisinde hepatik rezeksiyon uygulandi.

Anahtar kelimeler: Aberran hepatik kanal, safra yolu zedelenmesi

\section{GİRIS}

Safra yolu zedelenmeleri safra kesesi, pankreas ve mide ameliyatlarından sonra oluşsa da vakaların önemli bir kısmı kolesistektomilerden sonra görülmektedir. Zedelenmeler laparaskopik kolesistektomilerde açık kolesistektomilere göre daha fazla izlenir (\%0,4-\%0,7'ye karşın \%0,1-\%0,2) (1,2). Önemli bir sağlık problemi olan ve hastanın yaşam kalitesini olumsuz yönde etkileyen safra yolu zedelenmeleri klinikte kendilerini iki farklı durum ile gösterirler. 1lkinde zedelenmeye bağlı safra göllenmesi vardır, hastalar ameliyattan kısa süre sonra ateş, karın ağrısı gibi bulgularla başvururlar. Biliyer obstrüksüyon durumunda ise hastalarda sarllı ve kolanjit ataklarn izlenebilir (3). Biz burada safra kesesi ameliyatından 4 yl sonra kolanjit atakları ile tanısı konulan bir safra yolu zedelenmesi vakasını sunduk.

\section{OLGU}

Otuz dokuz yaşındaki kadın hasta karın ağrıları ile kliniğimize başvurdu. Son zamanlarda artan ağrılarına ateşlenmeleri de eşlik etmekteymiş. Hastaya 4 yll kadar önce safra kesesinde taş saptanıldığı için laparaskopik kolesistektomi ameliyatı yapılmıştı. Laboratuvarında hemoglobin 12,2, lökosit 8.820 , alanin aminotransferaz 15 , aspartat aminotransferaz 15 , gama glutamil transferaz 44 , total ve direk bilirubin değerleri normal, C-reaktif protein 17 ve sedimentasyon değeri 38 olarak geldi. Ultrasonografisinde karaciğer sağ lobda düzensiz sınırlı, içerinde ekojen imajları olan hipoekojen alan izlendi. Hastaya çekilen tomografide sağ lobda 5.-6. segmentlerde intrahepatik safra yolları ileri derecede dilateydi; dilate safra yolları içinde en büyüğu 9 mm olarak ölçülen multipl
Aberrant right hepatic duct is a bile duct variation which can be seen with 4.6\%-8.4\% frequency. Aberrant bile duct injuries present with different clinical presentations. Herein, we present a female patient who had intrahepatic stones and cholangitis attacks after a laparascopic cholecystectomy. Hepatic resection was performed for the treatment of this patient.

Key words: Aberrant hepatic duct, bile duct injury

taş ile uyumlu hiperdens görünümler vardı (Resim 1). Olası safra yolu hastalığının değerlendirilmesi için yapılan magnetik rezonans kolanjiyopankreatografi (MRCP)'de ise aberran sağ hepatik kanalın güdük yaparak sonlandığı ve bu kanalı drene ettiği safra yollarının genişlediği izlendi (Resim 2). Hastaya tip-B Strasberg safra yolu zedelenmesi tanısı konuldu. Semptomatik olan hastanın operasyonu planlandı. Cerrahi olarak sağ lobektomi yapıldı. Patolojide makroskopik olarak genişleyen duktuslarda gri renkli ve ortalama $0,5 \mathrm{~cm}$ çapında çok sayıda taş izlenirken (Resim 3) mikroskopik olarak genişleyen duktusların etrafında temel yapının ortadan kalktığl, asiner yapının yerini fibrozis alanlarına bıraktığı, miks inflamatuvar hücrelerin periduktal alanları infiltre ettiği görüldü.

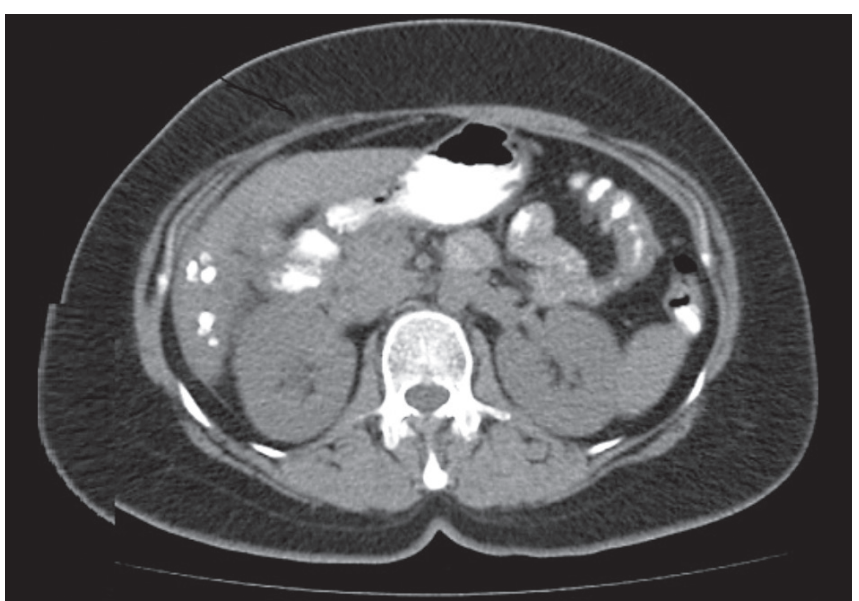

Resim 1. Intrahepatik taşlar. 


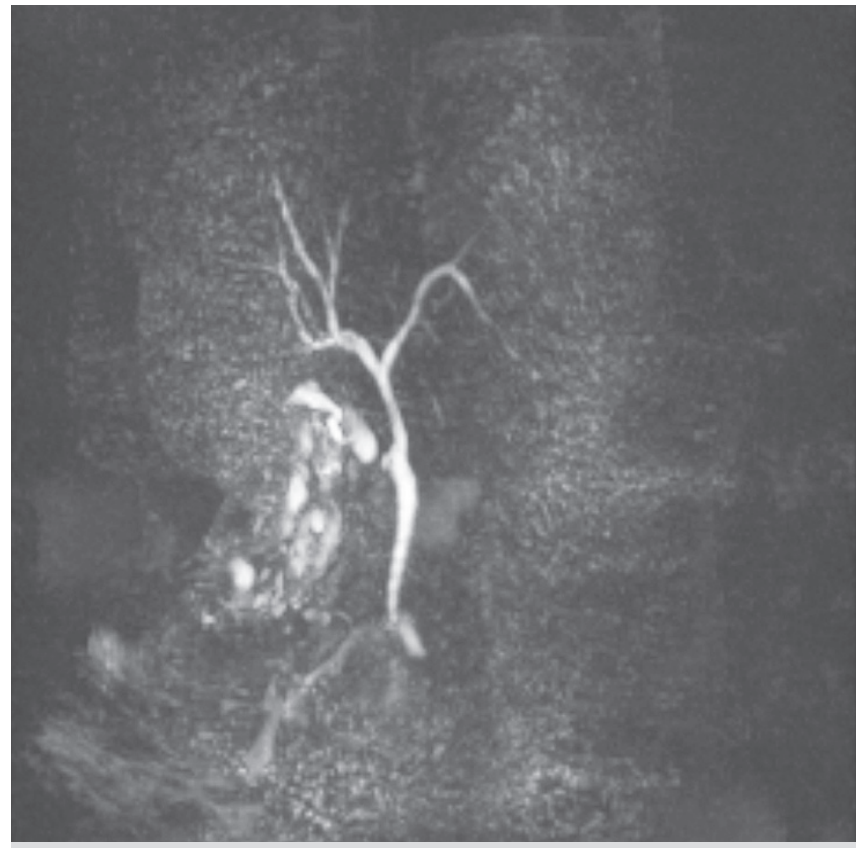

Resim 2. MRCP ile bağlanmış aberran sağ hepatik kanal güdügünün görünümü.

\section{TARTISSMA}

Safra yolu zedelenmeleri için farklı sınıflama sistemleri kullanılsa da Strasberg sinıflaması en çok tercih edilendir. Bu sınıflamada kendine tip-B ve tip-C'de yer bulan aberran sağ hepatik kanal, \%4,6-8,4 sıklıkta izlenen bir safra yolu varyasyonu olup sıklıkla ortak hepatik kanala veya sol hepatik kanala açılır ve sağ hepatik lobun değişken miktardaki safrasını drene eder (4). Tip-B zedelenme de aberran sağ hepatik kanalın bağlanmasını tanımlar. Strasberg-A ve D zedelenmesi olan hastalar klinikte kendilerini operasyondan kısa süre sonra oluşan ateş, karın ağrısı, sarılık ve lökositozla gösterirler (5). Strasberg-B zedelenmesi olan hastalar ise, zedelenen safra kanalı sağ karaciğer lobunun değişken miktarda safrasını drene ettiği için erken dönemde asemptomatik kalırlar; bununla beraber hastalarda klinikte yaygın halsizlik, kaşıntı, kolanjit atakları ve aralıklı olan karaciğer fonksiyonlarında bozulma da izlenebilir (6). Bizim hastamızın da ameliyattan sonra erken dönemde şikayeti olmamış, takip eden yıllarda karın ağrısı ve ateş şikayetleri oluşmuş ve bu nedenle yapılan incelemelerde tanı konulmuştur.

\section{KAYNAKLAR}

1- Adamsen S, Hansen OH, Funch-Jensen P, et al. Bile duct injury during laparoscopic cholecystectomy: a prospective nationwide series. J Am Coll Surg 1997;184:571-8.

2- Olsen D. Bile duct injuries during laparascopic cholecystectomy. Surg Endosc 1997;11:133-8.

3- Mercado MA, Dominguez I. Classification and management of bile duct injuries. World J Gastrointest Surg 2011 April 27;3:43-8.

4- Puente SG, Bannura GC. Radiological anatomy of the biliary tract: variations and congenital abnormalities. World J Surg 1983;7:271-6.

5- Suhocki PV, Meyers WC. Injury to aberrant bile ducts during cholecystectomy: a common cause of diagnostic error and treatment delay. AJR Am J Roentgenol 1999;172:955-9.

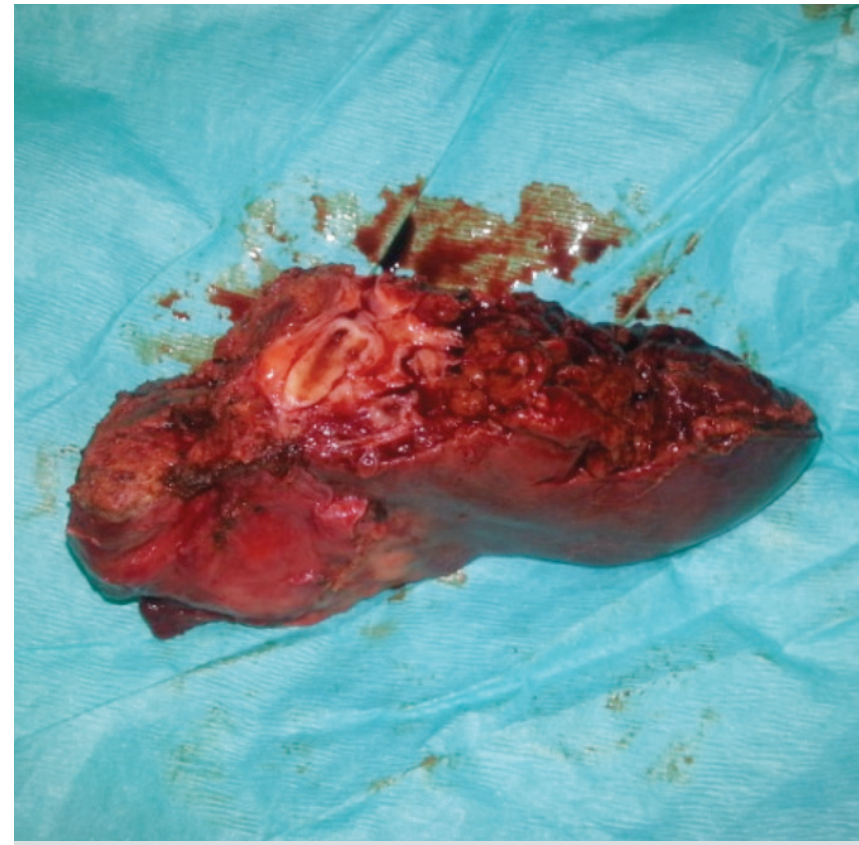

Resim 3. Sağ lobektomi materyalinde genişlemiş intrahepatik safra yolları.

Aberran sağ hepatik kanal zedelenmesi sonucunda bu kanala bağlanan daha küçük safra yollarında staz, dilatasyon, staza bağlı intrahepatik taş oluşması izlenebilir. Bu görünümüyle Caroli hastalı̆ı ile karışabilen tip-B zedelenmelerde safra kesesi ameliyatı öyküsü, Bilgisayarlı tomografi ve magnetik rezonans kolanjiopankreatografi ile safra yolu anatomisinin gösterilmesi ayırıcı tanıda yardımci olur (7)

Safra yolu zedelenmelerinde tedavi, safra yolu zedelenmesi tipine göre değişir. Tip-B zedelenmelerde hastalarda hafif karın ağrıları ve karaciğer fonksiyon testlerindeki yükselme varsa konservatif izlem önerilmektedir. Orta ve ciddi düzeyde kolanjit varlığı ise oklude segmentin perkütan ya da cerrahi drenajını gerekli kılar. Safra yolu zedelenmelerine bağlı sekonder biliyer siroz gelişen hastalarda ise karaciğer nakli diğer bir tedavi seçeneğidir (8). Bizim hastamızda da tekrarlayan kolanjit atakları ve görüntüleme yöntemlerinde izlenilen değişikliklerden dolayı tercih edilen tedavi yöntemi sağ lobektomi olmuştur.

6- Sofi AA, Alaradi HO, Abouljoud M, Nawras TA. Aberrant right hepatic duct draining into the cystic duct: Clinical outcomes and management. Gastroenterol Res Pract 2011;2011:458915.

7- Khalid TR, Casillas VJ, Montalvo BM, et al. Using MR cholangiopancreatography to evaluate latrogenic bile duct injury. AJR Am J Roentgenol 2001;177:1347-52.

8- Thomson BN, Parks RW, Madhavan KK, Garden OJ. Liver resection and transplantation in the management of iatrogenic biliary injury. World J Surg 2007;31:2363-9. 